Article

\title{
The Role of CzcRS Two-Component Systems in the Heavy Metal Resistance of Pseudomonas putida X4
}

\section{Pulin Liu ${ }^{1}$, Xi Chen ${ }^{1}$, Qiaoyun Huang ${ }^{1,2, *}$ and Wenli Chen ${ }^{1, *}$}

1 State Key Laboratory of Agricultural Microbiology, Huazhong Agricultural University, Wuhan 430070, China; E-Mails: liunan3585@163.com (P.L.); chenxi826@163.com (X.C.)

2 Key Laboratory of Arable Land Conservation (Middle and Lower Reaches of Yangtze River), Ministry of Agriculture, College of Resources and Environment, Huazhong Agricultural University, Wuhan 430070, China

* Authors to whom correspondence should be addressed;

E-Mails: qyhuang@mail.hzau.edu.cn (Q.H.); wlchen@mail.hzau.edu.cn (W.C.);

Tel.: +86-27-8767-1033 (Q.H.); Fax: +86-27-8728-0670 (Q.H.).

Academic Editor: Ji-Dong Gu

Received: 31 March 2015 / Accepted: 30 June 2015 / Published: 27 July 2015

\begin{abstract}
The role of different $c z c R S$ genes in metal resistance and the cross-link between $c z c R S$ and $c z c C B A$ in Pseudomonas putida X4 were studied to advance understanding of the mechanisms by which $P$. putida copes with metal stress. Similar to P. putida KT2440, two complete $c z c R S 1$ and $c z c R S 2$ two-component systems, as well as a $c z c R 3$ without the corresponding sensing component were amplified in P. putida X4. The histidine kinase genes $c z c S 1$ and $c z c S 2$ were inactivated and fused to $l a c Z$ by homologous recombination. The lac $Z$ fusion assay revealed that $\mathrm{Cd}^{2+}$ and $\mathrm{Zn}^{2+}$ caused a decrease in the transcription of $c z c R S 1$, whereas $\mathrm{Cd}^{2+}$ treatment enhanced the transcription of $c z c R S 2$. The mutation of different $c z c R S$ s showed that all $c z c R S$ s are necessary to facilitate full metal resistance in P. putida $\mathrm{X} 4$. A putative gene just downstream of $c z c R 3$ is related to metal ion resistance, and its transcription was activated by $\mathrm{Zn}^{2+}$. Data from quantitative real-time polymerase chain reaction (qRT-PCR) strongly suggested that $c z c R S$ s regulate the expression of $c z c C B A$, and a cross-link exists between different $c z c R S$ s.
\end{abstract}

Keywords: $c z c R S$; two-component system; metal resistance; Pseudomonas putida 


\section{Introduction}

Heavy metal pollution leads to serious ecological and health problems due to the toxic effects of metal ions and their accumulation throughout the food chain. Even the essential metal ions, $\mathrm{Zn}^{2+}, \mathrm{Cu}^{2+}$, and $\mathrm{Co}^{2+}$ could be toxic at high concentrations [1-3]. Many microorganisms naturally possess the ability to inhabit metal-polluted areas. An advanced understanding of the mechanisms by which microbes cope with metal stress will facilitate the rational design of strategies for detection and bioremediation of heavy metal-polluted water and soil systems.

To cope with metal stresses, bacteria develop various detoxification mechanisms. The most effective way is the extrusion of excessive metal ions out of the cell by active transport. A number of studies over the past years have been devoted to the protein families that export metal ions. The protein families include P-type ATPases driven by ATP hydrolysis, cation diffusion facilitator family transporters, which act as chemiosmotic ion-proton exchangers, and the resistance nodulation division (RND) family of transporters that mediate proton-driven efflux [4]. Usually, more than one kind of efflux protein is found in metal resistance bacteria [5,6]. CzcCBA is a CBA transporter. This structural gene region encodes outer membrane factors $\mathrm{CzcC}$, membrane fusion protein $\mathrm{CzcB}$, and $\mathrm{CzcA}$ protein of the resistance-nodulation-cell division protein family [4]. The transcriptional responses of these exporting genes are controlled by different regulators, including MerR family regulators [7], the ArsR/SmtB family [8], and two-component systems [9-11].

Many adaptive bacterial responses to environmental changes are governed by two-component signal transduction systems [12]. In typical two-component systems, environmental variation is first sensed by a histidine sensor kinase capable of autophosphorylation. The phosphoryl group is then transferred to an aspartic acid residue of the response regulator. Usually, the phosphorylated response regulator binds to DNA, resulting in either activation or repression of target genes. Caille et al. [9] observed that in P. aeruginosa PAO1, $\mathrm{Zn}^{2+}$ and $\mathrm{Cu}^{2+}$ enhance the expression of $c z c R S$. Phosphorylated CzcR then activates the expression of $c z c C B A$ operon encoding an efflux pump specific for zinc, cadmium, and cobalt. The copRS two-component system has been identified as key genes involved in copper resistance [13]. In Cupriavidus metallidurans $\mathrm{CH} 34$, the regulatory genes of $c z c C B A$ are arranged in an upstream region consisting of $c z c N$ and $c z c I$, and a downstream region consisting of $c z c D, c z c R$, $c z c S$ and $c z c E$ [14]. CzcRS and a periplasmic copper-binding protein designated CzcE [15], exert metal-dependent control of $c z c N I C B A$ expression via regulation of $c z c N p$ activity [16]. Grosse et al. [10] demonstrated that uninduced $C$. metallidurans $\mathrm{CH} 34$ with a mutation in $c z c S$ contains more $c z c C B A$ message and resumes growth faster when challenged. These pieces of evidence demonstrate the participation of two-component systems in the regulation of metal extrusion.

$P$. putida is a ubiquitous saprophytic bacterium, which has been extensively studied for the biodegradation of organic pollutants [17]. Although the genomes of $P$. putida contain several $c z c R S$ operons [5], no research has been reported regarding the simultaneous function of different $c z c R S \mathrm{~s}$ in the same strain. Our previous study indicated that $P$. putida X4 has a high tolerance and absorption capacity for metal ions [18]. In this study, PCR with primers designed from the homologous sequence in genome sequenced $P$. putida were used to detect the presence of $c z c R S$ two-component systems and the $c z c C B A$ operon. Because two $c z c R S$ two-component systems and one $c z c R 3$ without its corresponding sensor gene were detected, we examined their different roles and how they interacted with the $c z c C B A$ operon. 


\section{Results}

\subsection{Minimum Inhibitory Concentrations (MICs) of the Wild-Type and Mutant Strains}

The MIC values of the wild-type and mutant strains are shown in Table 1. Determination of heavy metal resistance showed that the strain $\mathrm{X} 4$ displayed a high level of $\mathrm{Cd}^{2+}, \mathrm{Co}^{2+}, \mathrm{Cu}^{2+}$, and $\mathrm{Zn}^{2+}$ resistance. The functionalities of $c z c S 1, c z c S 2$, and $c z c H$ were studied by determining the resistance of gene-deficient strains to different divalent heavy metals. $\Delta S 1$ tended to be sensitive to $\mathrm{Cd}^{2+}, \mathrm{Co}^{2+}$, and $\mathrm{Zn}^{2+}$ ions. The MIC of $\mathrm{Co}^{2+}$ and $\mathrm{Zn}^{2+}$ declined to 0.5 and $2.25 \mathrm{mmol} \cdot \mathrm{L}^{-1}$. The $c z c S 2$ mutation decreased the strain's resistance to $\mathrm{Cd}^{2+}$ and $\mathrm{Co}^{2+}$. Both $c z c S 1$ and $c z c S 2$ were required for generating full cadmium resistance as the $\triangle S 1 S 2$ strains with both interrupted $c z c S 1$ and $c z c S 2$ could tolerate only $1.25 \mathrm{mmol} \cdot \mathrm{L}^{-1} \mathrm{Cd}^{2+}$, which is lower than that tolerated by single gene mutant strains. Small but reproducible repression was observed when $\Delta S 1$ and $\Delta S 2$ were exposed to copper ions. A putative open reading frame (ORF), designated as $c z c H$ in this study, just downstream of $c z c R 3$, was identified as necessary to generate full metal tolerance. The resistance of $\Delta c z c H$ to $\mathrm{Cd}^{2+}, \mathrm{Co}^{2+}$, and $\mathrm{Zn}^{2+}$ were lower than that of the wild-type strains. The results presented above demonstrate that $c z c S 1, c z c S 2$, and $c z c H$ are necessary for the wild-type strain to generate full resistance to $\mathrm{Cd}^{2+}, \mathrm{Co}^{2+}, \mathrm{Cu}^{2+}$ and $\mathrm{Zn}^{2+}$.

Table 1. Minimum inhibitory concentrations (MICs) of cadmium, cobalt, copper, and zinc in various derivatives of $P$. putida $\mathrm{X} 4$.

\begin{tabular}{ccccc}
\hline \multirow{2}{*}{ Strains } & \multicolumn{4}{c}{ MIC $\left(\mathbf{m m o l} \cdot \mathbf{L}^{-\mathbf{1}}\right)^{\mathbf{a}}$} \\
\cline { 2 - 5 } & $\mathbf{C d}^{\mathbf{2 +}}$ & $\mathbf{C o}^{\mathbf{2 +}}$ & $\mathbf{C u}^{\mathbf{2}}$ & $\mathbf{Z n}^{\mathbf{2 +}}$ \\
\hline $\mathrm{X} 4$ & 4.5 & 4.0 & 5.0 & 8.5 \\
$\mathrm{X} 4$ with pvlt31 & 4.5 & 4.0 & 5.0 & 8.5 \\
$\Delta S 1$ & 3.0 & 0.5 & 4.25 & 2.25 \\
$\Delta S 2$ & 2.0 & 1.5 & 4.75 & 8.5 \\
$\Delta c z c H$ & 2.0 & 1.75 & 5.0 & 7.0 \\
$\Delta S 1 S 2$ & 1.25 & 0.5 & 4.25 & 5.0 \\
$\Delta S 1 c$ & 4.25 & 3.5 & 4.5 & 7.5 \\
$\Delta S 2 c$ & 4.25 & 4.0 & 4.75 & 8.5 \\
$\Delta c z c H c$ & 3.75 & 3.5 & 5.0 & 8.25 \\
\hline
\end{tabular}

${ }^{a}$ MICs were recorded after $60 \mathrm{~h}$ of growth at $30{ }^{\circ} \mathrm{C}$ on Tris-buffered medium containing metals salts from 0.5 to $10 \mathrm{mmol} \cdot \mathrm{L}^{-1}$, with $0.25 \mathrm{mmol} \cdot \mathrm{L}^{-1}$ interval. MIC values are the averages of four determinations.

\subsection{Genetic Complementation of Mutant Genes}

Complementation studies were carried out to confirm that the decreased resistance of strains $\Delta S 1, \Delta S 2$, and $\Delta c z c H$ to divalent metal ions was caused by the mutation of target genes. For the complementation analysis, the complete ORF of $c z c S 1, c z c S 2$ and $c z c H$ was cloned into the broad-host-range vector pVLT31, resulting in plasmids pVLTS1, pVLTS2 and pVLTH. Strains $\Delta S 1 c, \Delta S 2 c$ and $\Delta c z c H c$ were obtained by mating the complementation plasmid into P. putida $\Delta S 1, \Delta S 2$ and $\Delta c z c H$, respectively. The MICs of $\Delta S 1 c, \Delta S 2 c$ and $\Delta c z c H c$ were tested in Tris-buffered medium with $0.1 \mathrm{mmol} \cdot \mathrm{L}^{-1}$ IPTG using the method described above. The complementation data are shown in Table 1 . More than $85 \%$ of the tolerance to the tested metals was recorded for $\Delta S 1 c$ and $\Delta c z c H c$. The resistance of $\Delta S 2 c$ to $\mathrm{Co}^{2+}$ and $\mathrm{Cd}^{2+}$ were recorded at $100 \%$ and $94 \%$, respectively. At the same time, the MICs of control strains did not improve. 
2.3. $\mathrm{Cd}^{2+}$ and $\mathrm{Zn}^{2+}$ Repressed the Transcription of czcRS1, Induced the Transcription of czcRS2 and $\mathrm{czcH}$, Respectively

Expression patterns and inducer specificities were determined by measuring the changes of LacZ activity and verified by qRT-PCR. All promoters were tested for their inducibility in the presence of 0-180 $\mu \mathrm{mol} \cdot \mathrm{L}^{-1} \mathrm{Zn}^{2+}, \mathrm{Co}^{2+}, \mathrm{Cu}^{2+}$, and $\mathrm{Cd}^{2+}$. The expression patterns and inducer specificities of $c z c S 1$ are shown in Figure 1a. The $c z c S 1$ is transcribed without any metal ions. The transcription of $c z c S 1$ dropped to $40 \%$ in the presence of $180 \mu \mathrm{mol} \cdot \mathrm{L}^{-1} \mathrm{Zn}^{2+}$, then to $34 \%$ after a $180 \mu \mathrm{mol} \cdot \mathrm{L}^{-1} \mathrm{Cd}^{2+}$ treatment. Compared with $\mathrm{Zn}^{2+}$ and $\mathrm{Cd}^{2+}, \mathrm{Cu}^{2+}$ and $\mathrm{Co}^{2+}$ moderately decreased the transcription of $c z c S 1$. The transcription of $c z c S 2$ was only induced by $\mathrm{Cd}^{2+}$; LacZ activity in $\Delta S 2$ increased about 24 -fold after exposure to $180 \mu \mathrm{mol} \cdot \mathrm{L}^{-1} \mathrm{Cd}^{2+}$ (Figure $1 \mathrm{~b}$ ). The $c z c H$ gene was significantly induced by $\mathrm{Zn}^{2+}$, but was not affected by $\mathrm{Co}^{2+}, \mathrm{Cu}^{2+}$ and $\mathrm{Cd}^{2+}$. The highest level of $c z c H$ transcription was found at $100 \mu \mathrm{mol} \cdot \mathrm{L}^{-1}$ $\mathrm{Zn}^{2+}$ and it was decreased when the $\mathrm{Zn}^{2+}$ concentration was higher than $100 \mu \mathrm{mol} \cdot \mathrm{L}^{-1}$ (Figure 1c). These observations reveal that transcription from the promoters of $c z c S 1, c z c S 2$ and $c z c H$ are different, and that the main inducers or repressors are $\mathrm{Zn}^{2+}$ and $\mathrm{Cd}^{2+}$. qRT-PCR data confirmed the inducibility presented above (Figure 2); in the wild-type strain, addition of $300 \mu \mathrm{mol} \cdot \mathrm{L}^{-1} \mathrm{Cd}^{2+}$ or $\mathrm{Zn}^{2+}$ to the culture resulted in down-regulation of $c z c R S 1$ and up-regulation of $c z c R S 2$ and $c z c H$, respectively (30-, and 35-fold). Besides, the transcription of $c z c C B A$ was strongly induced by $\mathrm{Cd}^{2+}$ (90-fold) and $\mathrm{Zn}^{2+}$ (47-fold) to keep the equilibrium of these metal ions in the cells.

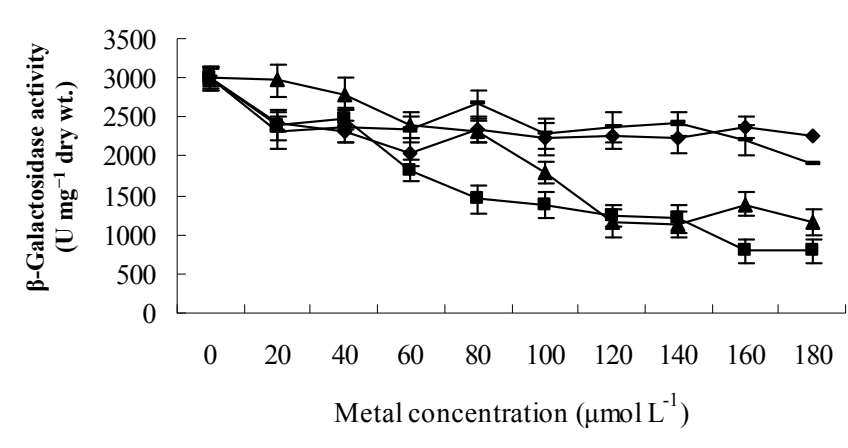

(a)

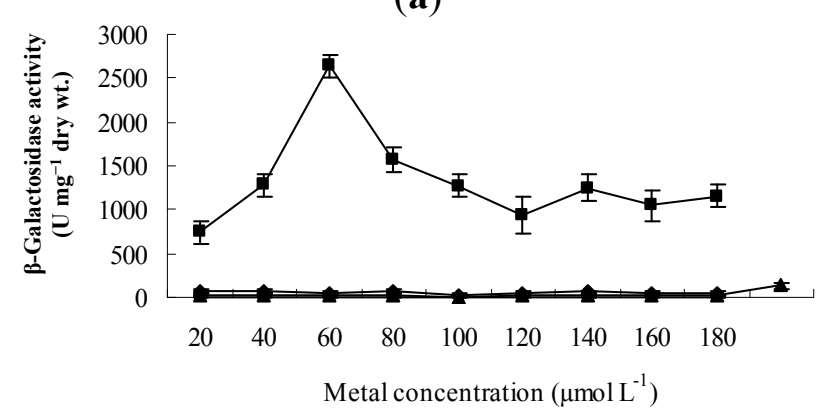

(c)

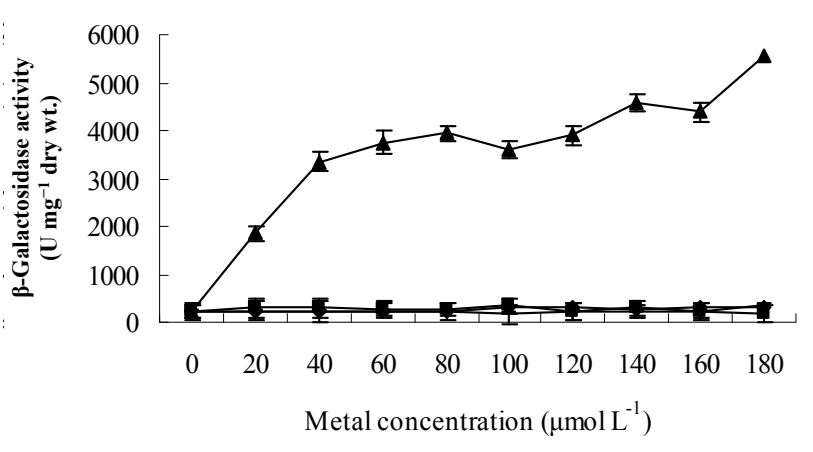

(b)

Figure 1. The expression patterns and inducer specificities of $c z c S 1, c z c S 2$, and $c z c H$. LacZ activity were measured in permeabilized cells after induction with different concentrations of $\mathrm{Cu}^{2+}(\bullet), \mathrm{Zn}^{2+}(\boldsymbol{\square}), \mathrm{Cd}^{2+}(\boldsymbol{\Delta})$, and $\mathrm{Co}^{2+}(-)$ for four hours. Error bars represent the standard deviations of three determinations. (a) Response of the promoter $c z c R S 1 p$ to different metal ions; (b) Response of the promoter $c z c R S 2 p$ to different metal ions; and (c) Response of the promoter $c z c H p$ to different metal ions. 


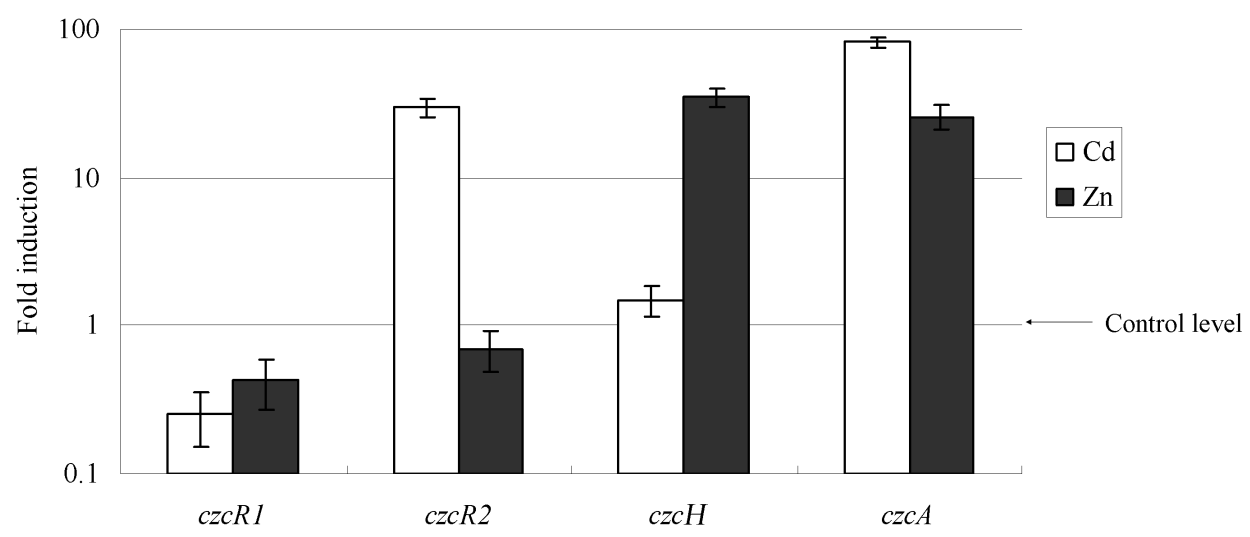

Figure 2. Transcription of $c z c R 1, c z c R 2, c z c H$, and $c z c A$ genes analyzed by qRT-PCR in the wild-type X4 strain grown in the presence of $300 \mu \mathrm{M} \mathrm{Zn}^{2+}$ or $\mathrm{Cd}^{2+}$. The amount of mRNA is represented relative to the $\mathrm{X} 4$ strain cultivated in the absence of metal ions. Error bars represent the standard deviations of three determinations.

\subsection{The Transcription Variation of Mutant Strains}

After treatment with $\mathrm{Cd}^{2+}$ or $\mathrm{Zn}^{2+}$, transcription of $c z c A$ was determined by qRT-PCR in the wild-type X4 strain and mutant strains. As shown in Figure 3, the mutation of $c z c S 1$ and $c z c S 2$ reduced the mRNA amount of $c z c A$ to $14 \%$, and $23 \%$ that of the wild-type, respectively, in the presence of $\mathrm{Cd}^{2+}$. A similar trend was detected upon induction with $\mathrm{Zn}^{2+}$. The mutation in $c z c H$ also caused repressed transcription of the $c z c A$. These findings show that all these three genes are required to maintain the expression of $c z c A$ at a high level. The transcript variation of $c z c R 1$ and $c z c R 2$ is shown in Figure 4. Compared with the wild-type, interruption of $c z c S 1$ enhanced the transcription of $c z c R l$ by 3.22- and 2.5 -fold, in the presence of $\mathrm{Cd}^{2+}$ and $\mathrm{Zn}^{2+}$, respectively. Mutation of $c z c S 2$ reduced the $c z c R 1$ and $c z c R 2$ mRNA to $40 \%$ and $2 \%$ of the wild type, while cultured with $\mathrm{Cd}^{2+}$. These transcription variations indicated that $c z c S 1$ in wild-type act negatively on the transcription of $c z c R 1$, and that functional $c z c S 2$ is needed to keep transcription of $c z c R 1$ and $c z c R 2$ at a relatively high level.

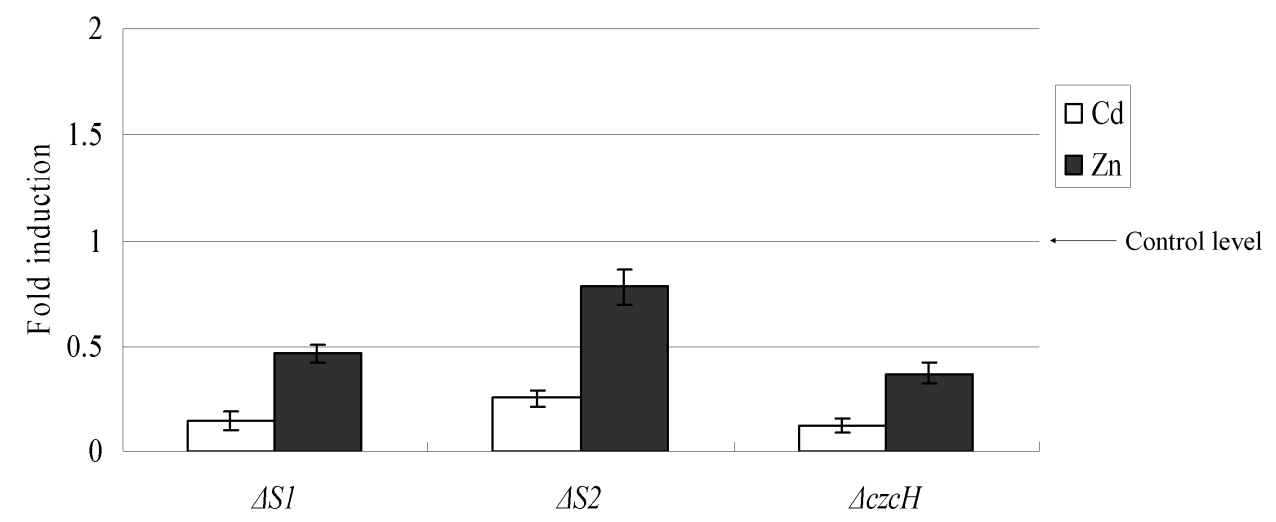

Figure 3. The effects of the mutation in $c z c S 1, c z c S 2$, and $c z c H$ on the transcription of $c z c A$. Transcription of $c z c A$ was analyzed by qRT-PCR in the wild-type X4 strain and mutant strains grown in the presence of $300 \mu \mathrm{M} \mathrm{Zn}^{2+}$ or $\mathrm{Cd}^{2+}$. The amount of mRNA is represented relative to the wild-type $\mathrm{X} 4$ strain cultivated in the same concentration of metal ions. Error bars represent the standard deviations of three determinations. 


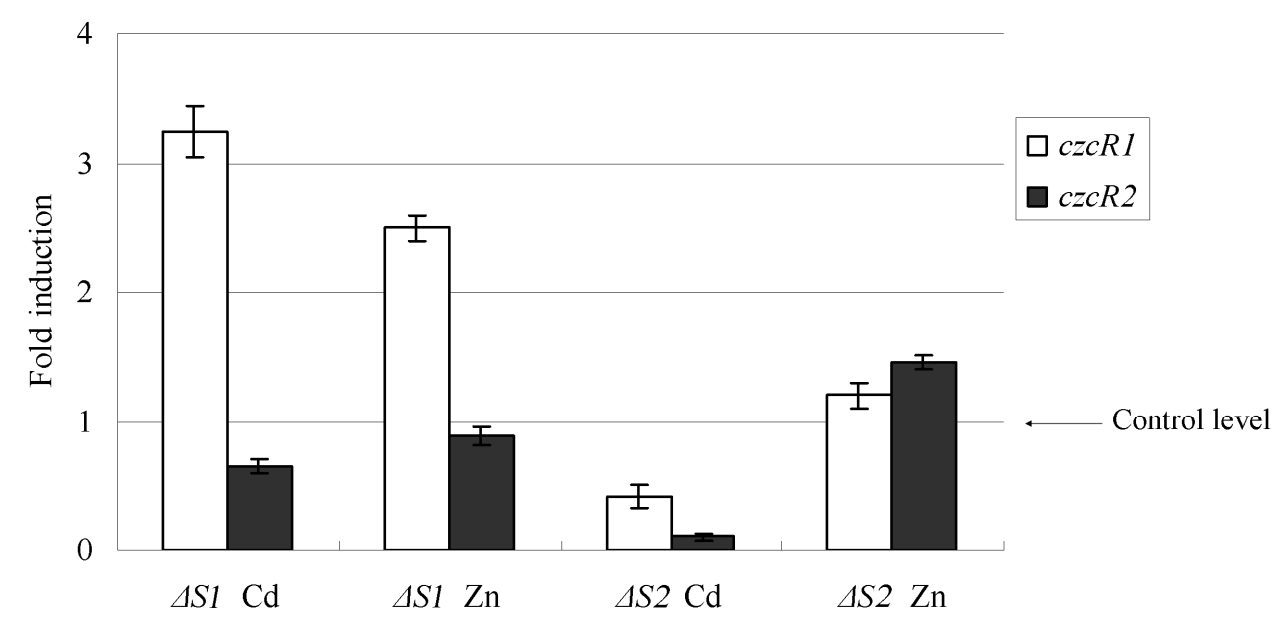

Figure 4. The effects of the mutation in $c z c S 1$ and $c z c S 2$ on the transcription of $c z c R l$ and $c z c R 2$. Transcription of $c z c R 1$ and $c z c R 2$ was analyzed by qRT-PCR in the wild-type X4

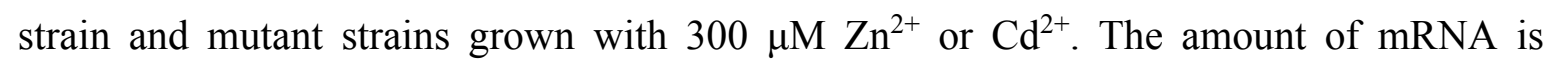
represented relative to the wild-type $\mathrm{X} 4$ strain cultivated in the same concentration of metal ions. Error bars represent the standard deviations of three determinations.

\subsection{Deposition of Strains and Nucleotide Sequences}

P. putida X4 was deposited in the China Center for Type Culture Collection (CCTCC, http://www.cctcc.org/) with accession number CCTCCM209319. The nucleotide sequences isolated in this study are available in the NCBI Genbank database: czcR1 (HQ676126), czcR2 (HQ676125), czcS1 (HQ676127), czcS2 (HQ676128), czcA (HQ676129), czcH (dsgR3, HQ676130), czcR3 (HQ676124). The similarities of deduced amino acid sequences of $c z c R$ and $c z c S$ genes are available in Table S1.

\section{Discussion}

In the present study, we demonstrate the roles played by the $c z c R S$ two-component systems in the control of $c z c C B A$ transcription as well as their different inducibility. To our knowledge, this is the first report on the functional difference of $c z c R S$ two-component systems in P. putida. Our results clearly show that all $c z c R S$ two-component systems are needed for $P$. putida $\mathrm{X} 4$ to generate full metal resistance. The reductions in MICs of $\mathrm{Zn}^{2+}, \mathrm{Co}^{2+}$, and $\mathrm{Cd}^{2+}$ in the $c z c S$ mutant strains were less than eight-fold. It cannot be excluded that $c z c C B A$ is also induced by other regulators, or that other transporters present in X4 may contribute to the intrinsic resistance of this organism to heavy metals. The amplified $c z c A$ in this study which is induced by $\mathrm{Zn}^{2+}$, and $\mathrm{Cd}^{2+}$ in wild type revealed a $>99 \%$ nucleotide identity with the $c z c C B A 1$ operon in P. putida KT2400. The $c z c C B A 1$ operon in P. putida KT2440 plays a major role in generating metal resistance to $\mathrm{Zn}^{2+}, \mathrm{Cd}^{2+}$, and possibly $\mathrm{Pb}^{2+}$ [6]. The $c z c C B A$ found in $C$. metallidurans $\mathrm{CH} 34$ confers resistance to $\mathrm{Zn}^{2+}, \mathrm{Co}^{2+}$, and $\mathrm{Cd}^{2+}[10]$. Similar systems have been found in $P$. aeruginosa PAO1 and $P$. aeruginosa CMG103 [9,19].

Plasmid pVIK112 was constructed by Kalogeraki et al. [20] to simultaneously disrupt and create fusions to target genes of diverse bacteria. The sequence of the fragment amplified in this study and the complete genome analysis of P. putida KT2440 [5] revealed that the czcRS in P. putida form separate operons and $c z c S s$ is located at the end of the operons. Therefore, a minimal polar effect was generated 
after single cross-over with pVIK112. The remarkable increase in metal resistance in the complementation strains supports this idea. Combining the data from the $\beta$-galactosidase activity assay and the transcription variation of $c z c R$ s and $c z c C B A$, the cross-interaction pathway among $\mathrm{Zn}^{2+}, \mathrm{Cd}^{2+}, c z c R S$ and $c z c C B A$ was depicted (Figure 5). The control of $c z c C B A$ expression through $c z c R S$ has been studied in $P$. aeruginosa and $C$. metallidurans [9-11]. Compared with previous studies, the regulation of $c z c C B A$ in P. putida was different. P. putida evolved two $c z c R S$ operons. Simultaneously, other regulation genes, such as $c z c N$ and $c z c I$ were not found in the P. putida sequenced genome. The expression of the CzcCBA efflux pump was induced by two $c z c R S$ operons with different inducibilities. The $c z c H$ gene also influenced the transcription of $c z c C B A$. The function of $c z c R S 1, c z c R S 2$ and $c z c H$ in P. putida X4 may be complementary. The transcription of $c z c R S 1$ was inhibited in the presence of $\mathrm{Zn}^{2+}$ and $\mathrm{Cd}^{2+}$, which may caused the reduced transcription of $c z c C B A$. However, a high level of efflux pump CzcCBA expression is essential for coping with high concentrations of metal ions (Figure 2). The low expression trend of $c z c C B A$ resulting from the CzcR1 may be compensated for by the induction effect caused by $c z c R S 2$ and $c z c H$, which were induced with $\mathrm{Cd}^{2+}$ and $\mathrm{Zn}^{2+}$, respectively. Complete $c z c R S 1$ negatively feedbacks on its expression, which creates a common regulating pathway in prokaryotes for maintaining the expression of transcription factors at appropriate levels [21]. Complete $c z c R S 2$ has a positive effect on the transcription of itself. This positive autoregulation loop could allow the cells to respond rapidly to the presence of small amounts of heavy metals in the environment [11].

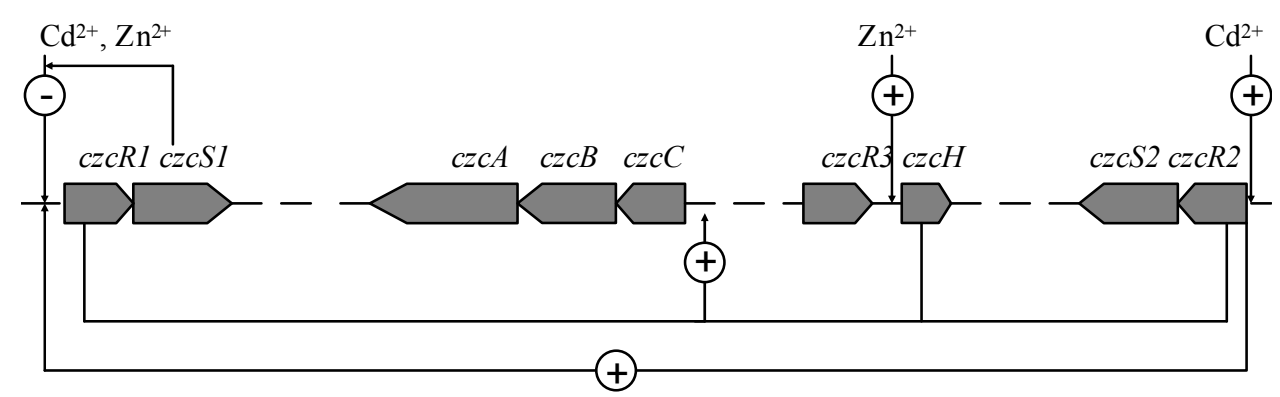

Figure 5. Model representing the cross-interaction among $\mathrm{Zn}^{2+}, \mathrm{Cd}^{2+}, c z c R S$, and $c z c A$. Based on the data from the LacZ fusion assay and qRT-PCR, the cross-talk among $\mathrm{Zn}^{2+}$, $\mathrm{Cd}^{2+}, c z c R S$, and $c z c A$ was depicted. $\mathrm{Zn}^{2+}$ and $\mathrm{Cd}^{2+}$ repressed the transcription of $c z c R S 1$, and induced the transcription of $c z c R S 2$ and $c z c H$, respectively. The $c z c R$ s and $c z c H$ gene could induce $c z c C B A$ transcription, leading to resistance to cobalt, zinc, and cadmium. Data from qRT-PCR also revealed a cross-interaction between $c z c R S 2$ and $c z c R S 1$.

In conclusion, there was a clear distinction between the different $c z c R S \mathrm{~s}$. $c z c R S 1$ is constitutively expressed and possibly acts as a housekeeping resistance mechanism against $\mathrm{Zn}^{2+}, \mathrm{Co}^{2+}$, and $\mathrm{Cd}^{2+}$ in P. putida X4. The transcription of $c z c R S 1$ was repressed by $\mathrm{Cd}^{2+}$ and $\mathrm{Zn}^{2+}$, whereas the transcription of $c z c R S 2$ was induced only by $\mathrm{Cd}^{2+}$. Both $c z c S 1$ and $c z c S 2$ act positively on the transcription of $c z c A$. Although $c z c H$ plays an important role in the metal resistance of $P$. putida X4, the underlying mechanism merits further studies. Different $c z c R S$ genes, along with other regulators, are needed to make precise adjustments to the gene expression of $P$. putida to adapt to changes in metal ions in the environment. 


\section{Materials and Methods}

\subsection{Bacterial Strains, Plasmids, and Growth Conditions}

Detailed information regarding the bacterial strains and plasmids are listed in Table 2. P. putida X4 was isolated from the waste soil around the Academy of Hubei Agricultural Sciences, Wuhan, China [22]. For construction and maintenance of plasmids, Escherichia coli strains DH5 $\alpha$ and C118גpir were used.

Table 2. Bacterial strains and plasmids used in this study.

\begin{tabular}{|c|c|c|c|}
\hline & & Relevant Characteristics ${ }^{a}$ & Reference \\
\hline \multirow{13}{*}{ } & E. coli & & \\
\hline & DH5 $\alpha$ & supE44 $\Delta l a c U 169$ (Ф80dlacZLM15) recA1 endA 1 hsdR 17 thi-1 gyrA96 relA 1 & Invitrogen \\
\hline & C118גpir & $\begin{array}{c}\Delta(\text { ara-leu }) \text { araD } \Delta l a c X 74 \text { galE galK phoA20 thi-1 rpsE rpoB argE (Am) } \\
\text { recA1 } \lambda \text { pir }\end{array}$ & [23] \\
\hline & MM294 & endA thiA hsdR17 supE44 & [24] \\
\hline & P. putida & & \\
\hline & $\mathrm{X} 4$ & $\mathrm{Ap}^{\mathrm{r}}, \mathrm{Co}^{\mathrm{r}}, \mathrm{Zn}^{\mathrm{r}}, \mathrm{Cd}^{\mathrm{r}}, \mathrm{Cu}^{\mathrm{r}}$, wild-type & [22] \\
\hline & $\Delta S 1$ & $\mathrm{X} 4 \Delta c z c S 1$ & This study \\
\hline & $\Delta S 1 c$ & $\mathrm{X} 4 \Delta c z c S 1$, with plasmid pVLTS1 & This study \\
\hline & $\Delta S 2$ & $\mathrm{X} 4 \Delta c z c S 2$ & This study \\
\hline & $\Delta S 2 c$ & $\mathrm{X} 4 \Delta c z c S 2$, with plasmid pVLTS2 & This study \\
\hline & $\Delta c z c H$ & $\mathrm{X} 4 \Delta c z c H$ & This study \\
\hline & $\Delta c z c H c$ & $\mathrm{X} 4 \Delta c z c H$, with plasmid pVLTH & This study \\
\hline & $\Delta S 1 S 2$ & $\mathrm{X} 4 \Delta c z c S 1 c z c S 2$ & This study \\
\hline \multirow{12}{*}{ 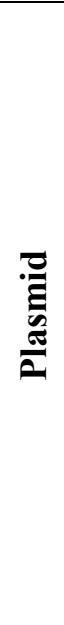 } & pRK2073 & RK2 helper plasmid, $\mathrm{Spe}^{\mathrm{r}}$ & [24] \\
\hline & pTA2 & Cloning vector, $\mathrm{Amp}^{\mathrm{r}}$ & TOYOBO \\
\hline & pVIK112 & LacZYA, $\mathrm{Km}^{\mathrm{r}}$, suicide vector & [20] \\
\hline & pVIKS1 & S1 fragment in pVIK112 & This study \\
\hline & pVIKS2 & $S 2$ fragment in pVIK112 & This study \\
\hline & pVIKH & $c z c H$ fragment in pVIK112 & This study \\
\hline & pRRT & Contains a $\mathrm{Tet}^{r}$ gene instead of $\mathrm{Km}^{r}$ cassette & This study \\
\hline & pRRTS2 & $S 2$ fragment in pRRT & This study \\
\hline & pVLT31 & lacI, $\mathrm{Tet}^{\mathrm{r}}$ & {$[25]$} \\
\hline & pVLTS1 & pVLT31 with $S 1$ ORF & This study \\
\hline & pVLTS2 & pVLT31 with $S 2$ ORF & This study \\
\hline & $\mathrm{pVLTH}$ & pVLT31 with $c z c H$ ORF & This study \\
\hline
\end{tabular}

${ }^{\mathrm{a}} \mathrm{Co}^{\mathrm{r}}, \mathrm{Zn}^{\mathrm{r}}, \mathrm{Cd}^{\mathrm{r}}$, and $\mathrm{Cu}^{\mathrm{r}}$ indicate resistance to cobalt, zinc, cadmium, and copper, respectively; $\mathrm{Amp}^{r}, \mathrm{Km}^{r}, \mathrm{Tet}^{r}$, and $S p e^{r}$ stand for resistance to ampicillin, kanamycin, tetracycline, and spectinomycin, respectively.

Bacteria were routinely grown in Luria-Bertani medium at $37^{\circ} \mathrm{C}($ E. coli $)$ or $30^{\circ} \mathrm{C}(P$. putida $)$. When required, antibiotics were added at the following final concentrations: for $E$. coli, $100 \mu \mathrm{g} / \mathrm{mL}$ ampicillin, $50 \mu \mathrm{g} / \mathrm{mL}$ kanamycin, and $12.5 \mu \mathrm{g} / \mathrm{mL}$ tetracycline; and for $P$. putida, $50 \mu \mathrm{g} / \mathrm{mL}$ kanamycin and $12.5 \mu \mathrm{g} / \mathrm{mL}$ tetracycline. Tris-buffered medium [26] containing $0.1 \%$ glucose was used for testing metal resistance and promoter inducibility. Analytical grade reagents $\mathrm{CuSO}_{4} \cdot 5 \mathrm{H}_{2} \mathrm{O}, \mathrm{CdCl}_{2} \cdot \mathrm{H}_{2} \mathrm{O}, \mathrm{ZnCl}_{2}$, and $\mathrm{CoCl}_{2} \cdot 6 \mathrm{H}_{2} \mathrm{O}$ were prepared into $1.0 \mathrm{M}$ stock solutions and sterilized by filtration. 


\subsection{Determination of MIC Values}

The minimum inhibitory concentrations (MICs) of trace metals were determined as previously described [26]. Briefly, bacteria cultures were spread onto the Tris-buffered medium containing metal salts from 0.5 to $10 \mathrm{mmol} \cdot \mathrm{L}^{-1}\left(0.25 \mathrm{mmol} \cdot \mathrm{L}^{-1}\right.$ interval $)$. The MICs were defined as the lowest concentration of metal salts at which no CFU were observed after $60 \mathrm{~h}$ of incubation at $30^{\circ} \mathrm{C}$.

\subsection{DNA Manipulation}

All primer pairs used in this study were shown in Table 3. Axygene mini-prep, PCR purification, and gel purification kits (Axygene, Union City, CA, USA) were chosen for DNA separation and purification. PCRs were carried out using Taq DNA polymerase. The plasmids were constructed using standard recombinant DNA techniques and introduced into E. coli by transformation. Plasmids derived from pVIK112 [20] were introduced into $P$. putida by triparental conjugation. The helper strain was E. coli MM294 with the helper plasmid pRK2073 [24]. The essential DNA fragment was verified by DNA sequencing.

Table 3. Primers used in this study.

\begin{tabular}{|c|c|c|c|}
\hline Purpose & Primer Pair & Sequence $\left(5^{\prime}-3^{\prime}\right)^{a}$ & Product Length (bp) \\
\hline \multirow{3}{*}{$\begin{array}{l}\text { For homologous } \\
\text { recombination }\end{array}$} & $\mathrm{S} 1$ & $\begin{array}{l}\text { gag cag acc tgg aag taa aga } \\
\text { ggt aga acc get caa aca a }\end{array}$ & 1113 \\
\hline & $\mathrm{S} 2$ & $\begin{array}{l}\text { cgt agg cta tgt act tga ggc g } \\
\text { tgt cgt tga tga tgc ggt tg }\end{array}$ & 920 \\
\hline & $\mathrm{czcH}$ & $\begin{array}{c}\text { cac agg gea ttc agg gac caa cge acg gga taa gag } \\
\text { gec egt tgc acc aca gat }\end{array}$ & 496 \\
\hline \multirow{5}{*}{ For qRT-PCR } & Qr1 & $\begin{array}{l}\text { aca acg gtg tag atg ctc tgc } \\
\text { cgg ctg gtc tta cgg atg g }\end{array}$ & 121 \\
\hline & Qr2 & $\begin{array}{l}\text { gcc gca acg acc agc aac } \\
\text { gac gca tca gca ggt gta gc }\end{array}$ & 144 \\
\hline & Qr3 & $\begin{array}{l}\text { atg atg ctg acg gcg aga ag } \\
\text { gcg aat gac ctc tac gga tgc }\end{array}$ & 162 \\
\hline & QczcA & $\begin{array}{l}\text { cca ctg agc acg acc aag g } \\
\text { aag gtg aag gaa gag gaa ggc }\end{array}$ & 128 \\
\hline & QrpsL & $\begin{array}{l}\text { ctg cgt aaa gta tgc cgt gtg } \\
\text { gcc cga agt atc cag aga gc }\end{array}$ & 174 \\
\hline \multirow{4}{*}{$\begin{array}{c}\text { For } \\
\text { complementation } \\
\text { experiment }\end{array}$} & CS1 & $\begin{array}{c}\text { cgg ggt acc taa gaa gga gat ata cca tga ggc cat tca gec tgg } \\
\text { cta gtc tag att aag cgg cgg tca ttg c }\end{array}$ & 1455 \\
\hline & $\mathrm{CS} 2$ & $\begin{array}{c}\text { cgg ggt acc taa gaa gga gat ata cettg aaa aac gec agc ctg tc } \\
\text { cta gtc tag atc act cgg cag gaa aca cca }\end{array}$ & 1419 \\
\hline & & cgg ggt acc taa gaa gga gat ata cca tga ggt & \\
\hline & $\mathrm{CczcH}$ & $\begin{array}{c}\text { ata gca ttg att atc agc a } \\
\text { cta gtc tag att ata aga agg cga gcg ag }\end{array}$ & 360 \\
\hline $\begin{array}{l}\text { For tetracycline } \\
\text { resistance gene }\end{array}$ & Tet & $\begin{array}{l}\text { cga cct gca gaa aat agg cgt atc acg agg } \\
\text { cag cet gca gtc tgc taa cca gta agg caa cga gg }\end{array}$ & 1560 \\
\hline
\end{tabular}

a underlined are restriction sites. 


\subsection{Homologous Recombination for Construction of czcS Mutants and lacZ Fusion Reporter Strains}

The suicide fusion vector $\mathrm{pVIK} 112$ was selected for the mutation and construction of a lacZ fusion reporter system. The plasmid pVIKS1 containing a $c z c S 1$ fragment was constructed as follows: the $c z c S 1$ fragment was cloned into pTA2 and its orientation was confirmed by sequencing. After digestion with $X b a \mathrm{I}$ and $K p n \mathrm{I}$, the restriction fragment was cloned into pVIK112 to create pVIKS1. The same procedure was then employed to create plasmids pVIKS2 and pVIKH. These plasmids were introduced into $P$. putida $\mathrm{X} 4$ by triparental conjugation. To generate double $c z c S$ mutation strain $\triangle S 1 S 2$, another suicide plasmid pRRT was constructed by replacing lacZYA and the kanamycin resistance gene cassette in pVIK112 into a tetracycline resistance gene by PstI digestion. After ligating with $c z c S 2$ restriction fragment from pTA2, the plasmid was applied to generate double mutation based on the $\Delta S 1$.

\section{5. $\beta$-Galactosidase Activity Assay}

The activity of $\beta$-galactosidase was measured according to the method by Nies [27] using $o$-nitrophenyl-D-galactoside $(4 \mathrm{mg} / \mathrm{mL})$ as the substrate. The unit $1 \mathrm{U}$ was defined as the activity that forms $1 \mathrm{nmol}$ of $o$-nitrophenol per minute at $30^{\circ} \mathrm{C}$.

\subsection{Complementation Experiment}

Complementation experiments were carried out to confirm that the phenotype variation is caused by the $c z c S$ mutant. Two $c z c S$ and the $c z c H$ open reading frames (ORFs) were amplified using the total DNA from $P$. putida $\mathrm{X} 4$ as the template. After digestion with $X b a \mathrm{I}$ and $K p n \mathrm{I}$, the amplified fragments were ligated into the broad-host-range expression vector pVLT31, which contains the lacI and tac promoter [25], yielding pVLTS1, pVLTS2, and pVLTH. The yielded plasmids were mated into mutant strains $\Delta S 1, \Delta S 2$, and $\Delta c z c H$ respectively via conjugation. The MICs of the different transconjugants were checked as described above with IPTG induction. Control strains were constructed by transformed pVLT31 into $\Delta S 1, \Delta S 2$, and $\Delta c z c H$.

\subsection{RNA Isolation and Quantitative Real-Time Polymerase Chain Reaction (qRT-PCR) Analysis}

After $\mathrm{Cd}^{2+}$ or $\mathrm{Zn}^{2+}$ treatment, the total RNA for qRT-PCR was extracted using the RNA bacteria protect solution and the RNeasy kit (Qiagen, Hilden, Germany) according to the manufacturer's instructions. The residual DNA was eliminated by treatment with $20 \mathrm{U}$ RQ1 RNase-free DNase (Promega, Madison, WI, USA) followed by phenol-chloroform extraction. The RNA was precipitated with ethanol and resuspended in RNase-free water. For cDNA synthesis, $3 \mu \mathrm{g}$ of RNA was reverse transcribed using random hexamer primers and MLV reverse transcriptase (Promega) according to the supplier's instructions. Reverse transcriptase was inactivated by incubation at $70{ }^{\circ} \mathrm{C}$ for $15 \mathrm{~min}$ and the obtained cDNAs were stored at $-20^{\circ} \mathrm{C}$ until utilization. The cDNAs were quantitatively measured with a Bio-Rad iCycler machine (Bio-Rad, Berkeley, CA, USA) using a Sybr Green Quantitect kit (Qiagen). The primer pairs used for qRT-PCR were designed using the Primer3 [28] program. To check for contaminated DNA, control reactions without reverse transcriptase were analyzed using $r p s L$ primer set. The pure RNA samples were obtained when no amplification of the non-template control was detected. The cDNA samples were diluted 10 -fold and $1 \mu \mathrm{L}$ of the dilution served as the PCR template, which 
was performed in duplicate for each gene and sample. To offset the difference in the amount of cDNAs, the ribosomal rpsL gene was chosen as the reference gene. Results are presented as the ratios of gene expression between the target gene (target) and the reference gene ( $r p s L)$, which were obtained according to

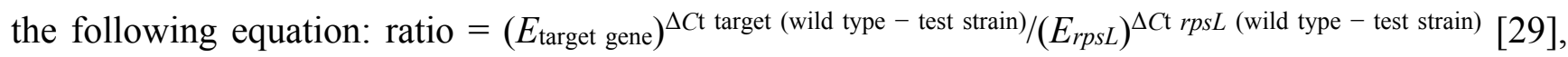
where $E$ is the real-time PCR efficiency of a given gene and $C t$ is the crossing point of the amplification curve with the threshold. An effect on gene transcription was considered significant when the corresponding ratios were $\geq 2.0$ or $\leq 0.5$.

\section{Supplementary Materials}

Supplementary materials can be found at http://www.mdpi.com/1422-0067/16/08/17005/s1.

\section{Acknowledgments}

This work was supported by National High Technology Research and Development Program of China ("863" Program, 2012AA101402), the National Natural Science of Foundation of China (41230854) and the Program for Changjiang Scholars and Innovative Research Team in University of China (IRT1247). The authors gratefully acknowledge the help of Steven Vinans from Cornell University, Ithaca, NY, USA, for providing plasmid pVIK112.

\section{Author Contributions}

Wenli Chen and Qiaoyun Huang conceived the experiment; Pulin Liu performed the experiment and wrote the paper; Xi Chen contributed qRT-PCR data analysis and English revision.

\section{Conflicts of Interest}

The authors declare no conflict of interest.

\section{References}

1. Blindauer, C.A.; Harrison, M.D.; Parkinson, J.A.; Robinson, A.K.; Turner-Cavfet, J.S.; Robinson, N.J.; Sadler, P.J. A metallothionein containing a zinc finger within a four-metal cluster protects a bacterium from zinc toxicity. Proc. Natl. Acad. Sci. USA 2001, 98, 9593-9598.

2. Fantino, J.R.; Py, B.; Fontecave, M.; Barras, F. A genetic analysis of the response of Escherichia coli to cobalt stress. Environ. Microbiol. 2010, 12, 2846-2857.

3. Solioz, M.; Stoyanov, J.V. Copper homeostasis in Enterococcus hirae. FEMS Microbiol. Rev. 2003, 27, 183-195.

4. Nies, D.H. Efflux-mediated heavy metal resistance in prokaryotes. FEMS Microbiol. Rev. 2003, 27, 313-339.

5. Cánovas, D.; Cases, I.; de Lorenzo, V. Heavy metal tolerance and metal homeostasis in Pseudomonas putida as revealed by complete genome analysis. Environ. Microbiol. 2003, 5, 1242-1256.

6. Leedjarv, A.; Ivask, A.; Virta, M. Interplay of different transporters in the mediation of divalent heavy metal resistance in Pseudomonas putida KT2440. J. Bacteriol. 2008, 190, 2680-2689. 
7. Brown, N.L.; Stoyanov, J.V.; Kidd, S.P.; Hobman, J.L. The MerR family of transcriptional regulators. FEMS Microbiol. Rev. 2003, 27, 145-163.

8. Wu, J.; Rosen, B.P. Metalloregulated expression of the ars operon. J. Biol. Chem. 1993, 268, $52-58$.

9. Caille, O.; Rossier, C.; Perron, K. A copper-activated two-component system interacts with zinc and imipenem resistance in Pseudomonas aeruginosa. J. Bacteriol. 2007, 189, 4561-4568.

10. Große, C.; Grass, G.; Anton, A.; Franke, S.; Santos, A.N.; Lawley, B.; Brown N.L.; Nies, D.H. Transcriptional organization of the $c z c$ heavy-metal homeostasis determinant from Alcaligenes eutrophus. J. Bacteriol. 1999, 181, 2385-2393.

11. Perron, K.; Caille, O.; Rossier, C.; van Delden, C.; Dumas, J.L.; Köhler, T. CzcR-CzcS, a two-component system involved in heavy metal and carbapenem resistance in Pseudomonas aeruginosa. J. Biol. Chem. 2004, 279, 8761-8768.

12. Casino, P.; Rubio, V.; Marina, A. The mechanism of signal transduction by two-component systems. Curr. Opin. Struct. Biol. 2010, 6, 763-771.

13. Teitzel, G.M.; Geddie, A.; de Long, S.K.; Kirisits, M.J.; Whiteley, M.; Parsek, M.R. Survival and growth in the presence of elevated copper: Transcriptional profiling of copper-stressed Pseudomonas aeruginosa. J. Bacteriol. 2006, 188, 7242-7256.

14. Van der Lelie, D.; Schwuchow, T.; Schwidetzky, U.; Wuertz, S.; Baeyens, W.; Mergeay, M.; Nies, D.H. Two-component regulatory system involved in transcriptional control of heavy-metal homoeostasis in Alcaligenes eutrophus. Mol. Microbiol. 1997, 23, 493-503.

15. Petit-Haertlen, I.; Girard, E.; Sarret, G.; Hazemann, J.; Gourhant, P.; Kahn, R.; Coves, J. Evidence for conformational changes upon copper binding to Cupriavidus metallidurans CzcE. Biochemistry 2010, 49, 1913-1922.

16. Grosse, C.; Anton, A.; Hoffmann, T.; Franke, S.; Schleuder, G.; Nies, D.H. Identification of a regulatory pathway that controls the heavy-metal resistance system $\mathrm{Czc}$ via promoter $c z c N p$ in Ralstonia metallidurans. Arch. Microbiol. 2004, 182, 109-118.

17. Timmis, K.N. Pseudomonas putida: A cosmopolitan opportunist par excellence. Environ. Microbiol. 2002, 4, 779-781.

18. Fang, L.C.; Cai, P.; Li, P.X.; Wu, H.Y.; Liang, W.; Rong, X.; Chen, W.; Cai, P. Microcalorimetric and potentiometric titration studies on the adsorption of copper by $P$. putida and B. thuringiensis and their composites with minerals. J. Hazard. Mater. 2010, 181, 1031-1038.

19. Hassan, M.T.; van der Lelie, D.; Springael, D.; Romling, U.; Ahmed, N.; Mergeay, M. Identification of a gene cluster, czr, involved in cadmium and zinc resistance in Pseudomonas aeruginosa. Gene 1999, 238, 417-425.

20. Kalogeraki, V.S.; Winans, S.C. Suicide plasmids containing promoterless reporter genes can simultaneously disrupt and create fusions to target genes of diverse bacteria. Gene 1997, 188, 69-75.

21. Stekel, D.J.; Jenkins, D.J. Strong negative self regulation of prokaryotic transcription factors increases the intrinsic noise of protein expression. BMC Syst. Biol. 2008, 2, 6.

22. Fu, Y.J.; Chen, W.L.; Huang, Q.Y.; Construction of two lux-tagged $\mathrm{Hg}^{2+}$-specific biosensors and their luminescence performance. Appl. Microbiol. Biotechnol. 2008, 79, 363-370. 
23. Keseler, I.M.; Collado-Vides, J.; Gama-Castro, S.; Ingraham, J.; Paley, S.; Paulsen, I.T.; Peralta-Gil, M.; Karp, P.D. A comprehensive database resource for Escherichia coli. Nucleic Acids Res. 2005, 33, 334-337.

24. Hu, G.Y.; Li, Y.G.; Zhou, J.C. Biological characteristics of plasmids of Mesorhizobium huakuii HN3015 from Astragalus sinicus. World J. Microbiol. Biotechnol. 2007, 23, 845-851.

25. De Lorenzo, V.; Eltis, L.; Kessler, B.; Timmis, K.N. Analysis of Pseudomonas gene products using lacIq/Ptrp-lac plasmids and transposons that confer conditional phenotypes. Gene 1993, 123, $17-24$.

26. Mergeay, M.; Nies, D.H.; Schlegel, H.G.; Gerits, J.; Charles, P.; van Gijsegem, F. Alcaligenes eutrophus $\mathrm{CH} 34$ is a facultative chemolithotroph with plasmid bound resistance to heavy metals. J. Bacteriol. 1985, 162, 328-334.

27. Nies, D.H. CzcR and CzcD, gene-products affecting regulation of resistance to cobalt, zinc, and cadmium (czc system) in Alcaligenes eutrophus. J. Bacteriol. 1992, 174, 8102-8110.

28. Rozen, S.; Skaletsky, H. Primer3 on the WWW for general users and for biologist programmers. Methods Mol. Biol. 2000, 132, 365-386.

29. Pfaffl, M.W.; Horgan, G.W.; Dempfle, L. Relative expression software tool (RESTC) for group wise comparison and stastical analysis of relative expression results in real-time PCR. Nucleic Acids Res. 2002, 30, doi:10.1093/nar/30.9.e36.

(C) 2015 by the authors; licensee MDPI, Basel, Switzerland. This article is an open access article distributed under the terms and conditions of the Creative Commons Attribution license (http://creativecommons.org/licenses/by/4.0/). 